\title{
PROCEDURES IN STRUCTURING VERBAL SENTENCES IN TEACHING AND LEARNING MALAY-ARABIC TRANSLATION COURSE
}

\author{
1*Taj Rijal Muhamad Romli, ${ }^{1}$ Ariza Abdullah, ${ }^{1}$ Mohd Hilmi Abdullah \\ Department of Modern Languages, Faculty of Languages and Communication, Universiti Pendidikan Sultan Idris, 35900 Tanjung \\ Malim, Perak, Malaysia ${ }^{1}$ \\ Corresponding email: taj.rijal@ fbk.upsi.edu.my
}

\begin{abstract}
This paper discusses the procedures used in teaching and learning Malay-Arabic translation courses for students of Bachelor of Arabic Studies with Education.This procedure is designed to facilitate the problem of students in structuring Arabic sentences based on the correct method of translation. Referring to the natural translation theory by Nida and Taber that prioritizes message delivery despite changes to the original text. This method was introduced as an alternative to students to construct Arabic sentences when translating according to the procedure that has been designed systematically for teaching and learning (T\&L). This procedure is divided into five steps. The first step is understanding the text through intensive reading. Next, in the second step is finding the meaning of difficult phrases by using dictionary and discussion. The third step, which is the main basis of the procedure is breaking the paragraphs of text into short sentences based on verb phrases. The fourth step is categorizing each sentence into the Arabic syntax structure for verb phrases. The fifth step is compiling and building a draft sentence which is translated directly through the translation text based on the steps above. The outcome of using this procedure increases the quality of Malay-Arabic translation and making it more understandable as students apply the structure of a correct Arabic sentence. This procedure will be used as an alternative for students in practising scientific translation in accordance with translation procedures.
\end{abstract}

Keywords: procedures, structures, sentences, translation, Malay-Arabic

Article Received: 18 October 2020, Revised: 3 November 2020, Accepted: 24 December 2020

\section{Introduction}

This paper aims to introduce procedures in structuring sentences using Arabic verbal phrases based on Malay- Arabic translation techniques taught in the third semester of translation classes for the Elementary Translation course and sixth semester for the Applied Translation course for students of Bachelor of Arabic Studies with Education at UPSI.

This technique was first introduced to students in the $6^{\text {th }}$ semester for the session of 2016/2017 after going through several phases of using semantic and free translation methods. However, in view of the limitations of students who are able to master good Malay-Arabic translation using semantic and free techniques, lecturers have to use a variety of other techniques and methods to achieve the objective that students are capable to translate at least the meaning of sentences into simple.standard Arabic grammar structure.

In the practice of translation, the method used must be text-based. The main difference is that students need to understand the original text first, choose the right word and structure the new sentence. Students are relatively text-bound and not free. This complexity is simplified by the introduction of several translation theories such as meaning translation and free translation theory to give students a chance to structure sentences comfortably. Besides, the comparable method of Malay-Arabic equivalent texts also expose students to the structure of Arabic sentences.

The practice of translating Malay-Arabic texts is much more complicated than translating ArabicMalay texts. This is due to the weakness of the students themselves who do not master the writing skills. The issues of the students' weaknesses have been discussed in detail by national researchers and academicians. The weaknesses in Arabic writing are found in five aspects, namely orthography and spelling, syntax and morphology, sentence structure, vocabulary and strategy (Sumaiyah Sulaiman, 2018). 
Arabic language students experienced this problem since the school years and weakness was further brought to the university level. The problem becomes more apparent when focused on the weakness of structuring phrases and sentences, which is the main means for effective communication as found by studies such as Rosni (2012), Che Radiah (2009), Noor Anida binti Awang, Norhayati Binti Che Hat and Nurazan binti Mohmad Rouyan (2014) and Ghazali Yusri and Ahmad Bin Salleh (2006).

Based on the studies above, among the factors that lead to this weakness is due to the fact that the students are affected by the structure of their mother tongue. Other reasons are, low mastery of Arabic vocabulary, negligency and no high motivation in learning. This weakness can be seen through significant mistakes in their writing and also in their translation texts from Malay into Arabic language (Al Muhsin et al., 2020). The usage of dictionary is not enough help to convey the translation's meaning, because the dictionary only translate words and phrases. The example given is also limited. Even if the students were able to find the meaning of each word but they still have trouble in structuring sentences into Arabic.

Rosni Samah (2012) found that university students who graduated from religious secondary schools were more capable of structuring Arabic nominal phrases comparing to verbal phrases because the structure of nominal phrase was more similar to the structure of the Malay phrase. Among other factors contributing to the students' weakness in writing and developing perfect Arabic verbal phrases are lack of vocabulary, lack of grammar training, lack of assessment techniques in writing and inadequate reference materials in Arabic (Zulkifli, 2000). Jassem Ali (2000) stated that students' error in constructing Arabic sentences included misusage of verbal sentences and usage of particles. These students' weaknesses at schools are carried until they continue their studies at university, some of whom are having trouble distinguishing between verbs and nouns, and not being able to construct a sentence pattern correctly.

Saipolbarin et al. (2018) introduced verb phrase formulas that use transitive verbs called "apple fruit" sentences and verbs that use non-transitive verbs called "go to school" sentences. This study was created as an effort to enhance the skills of UPSI trainee teachers who will teach Arabic in schools across the country. This formula was then developed into a Kit-media model of Arabic verb phrase pattern with six main components involving the two sentence patterns above (Saipolbarin et al., 2019).

Taj Rijal (2015), introduced comparable method in learning Malay and Arabic structures. Through this method, it can be used to search for comparabilities in texts and sentences between the first language and the second. Each text identified as having immediate equivalent will be used as teaching and learning tool in the classroom. It helps students to Arabic translators in structuring new sentences into Arabic by comparing and evaluating the original texts in the corpus. At the same time students are able to understand and recognize indirectly the structure of the original Arabic sentences

\section{Malay-Arabic Translation Procedures}

During T\&L of translation course, students are reinforced with recognition of Arabic sentence structures before entering the translation stage. In Arabic syntax, sentence is divided into two structures, namely nominal sentence and verbal sentence. Based on these structures, transformation is applied by the addition of a functional word or phrase. Verbal sentence requires verb and noun in a sentence. Arabic is constructed based on 'VS' rule [V=Verb, S=Subject] (Azman Che Mat et. al, 2014). The areas of differences between Arabic and Malay in verbal system can be specified in tense, in Arabic is an inflectional category which locates the action expressed by a verb at a time relative to the moment of speaking past, present and future, while in Malay tense may be expressed by auxiliaries (Asem, 2013). 
This method is introduced to students in five steps. The first step is to read and understand the text. The second step is to find and solve complex word phrases or sentences to translate into Arabic. The third step separates the text of the paragraphs into short sentences based on verb phrases and translation into Arabic. Students are encouraged to use colored markers or recognizable markers to express the verbs and nouns (performers) in verb phrases. The fourth step is the process of categorizing each sentence which is divided into the Arabic syntax structure of fi'il, fail, maf'ulun bihi / syibh al-jumlah and mukammil al-jumlah as set forth in table 1 . The fifth step is to compile and build a draft sentence in a perfect paragraph. These Five Steps are illustrated in the following figure 1:

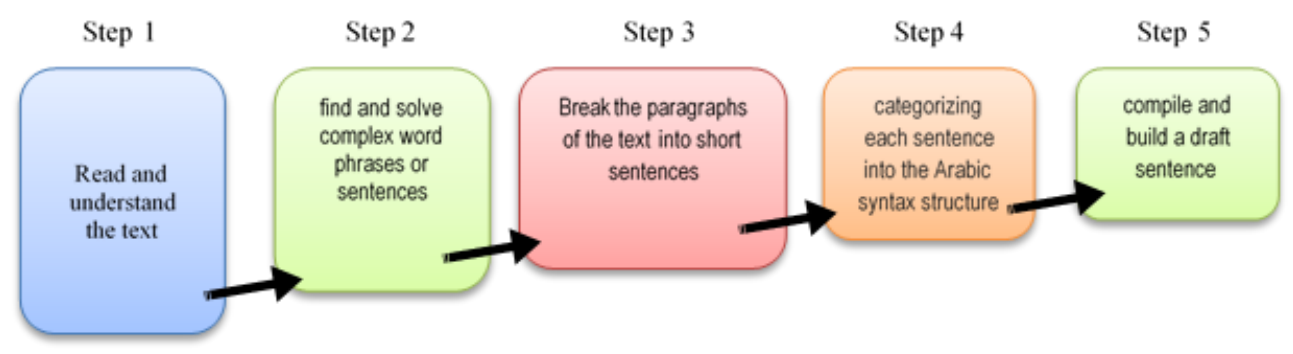

Figure 1. Translation procedure for Malay-Arabic verb sentence

\section{Example: Exercise 1}

Text is selected based on the difficulty level of the translation and considering the students' ability. In this step, students are asked to read intensively to gain an in-depth overview of the textual content and sentence structure that will be translated into Arabic. If students find it difficult to transfer information, they move on to the second step by searching for the meaning and words' meaning by discussing, using a dictionary or asking questions.

\section{Text 1}

"Beruang putih hidup di Kutub Utara di mana cuacanya teramatlah sejuk dan airnya menjadi beku. Ia langsung tidak mengendahkan keadaan cuaca yang sejuk sebegitu kerana bulunya tebal. Tidak ada beza baginya antara daratan dan lautan, berenang di lautan sama juga seperti ia berjalan di atas daratan."

Beruang putih hidup di Kutub Utara / di mana cuacanya teramatlah sejuk dan airnya menjadi beku. / Ia langsung tidak mengendahkan keadaan cuaca yang sejuk sebegitu kerana bulunya tebal. / Tidak ada beza baginya antara daratan dan lautan,/ berenang di lautan sama juga seperti ia berjalan di atas daratan.

Beruang putih hidup di Kutub Utara / di mana cuacanya teramatlah sejuk dan airnya menjadi beku. I

Ia langsung tidak mengendahkan keadaan cuaca yang sejuk sebegitu kerana bulunya tebal. / Tidak ada beza baginya antara daratan dan lautan,/

berenang di lautan sama juga /

seperti ia berjalan di atas daratan.

In the third step, the paragraph of Text 1 above is divided into sentences based on the verb (فعل) as in Table 1 below. Then in the fourth atan the students have to complete the table wow by entering the verb in the fi'il box, the noun performer in the $f a>$ 'il box, the object / preposition in the maf'ulun bihi/ syibh al-jumlah box and complemantary sentence in the mukammil al-jumlah box. At this point, students need to be aware of the different tenses for verb step 3 , the singular and plural (mufrad, jama', muthanna) as well as masculine and feminine changes in Arabic. 


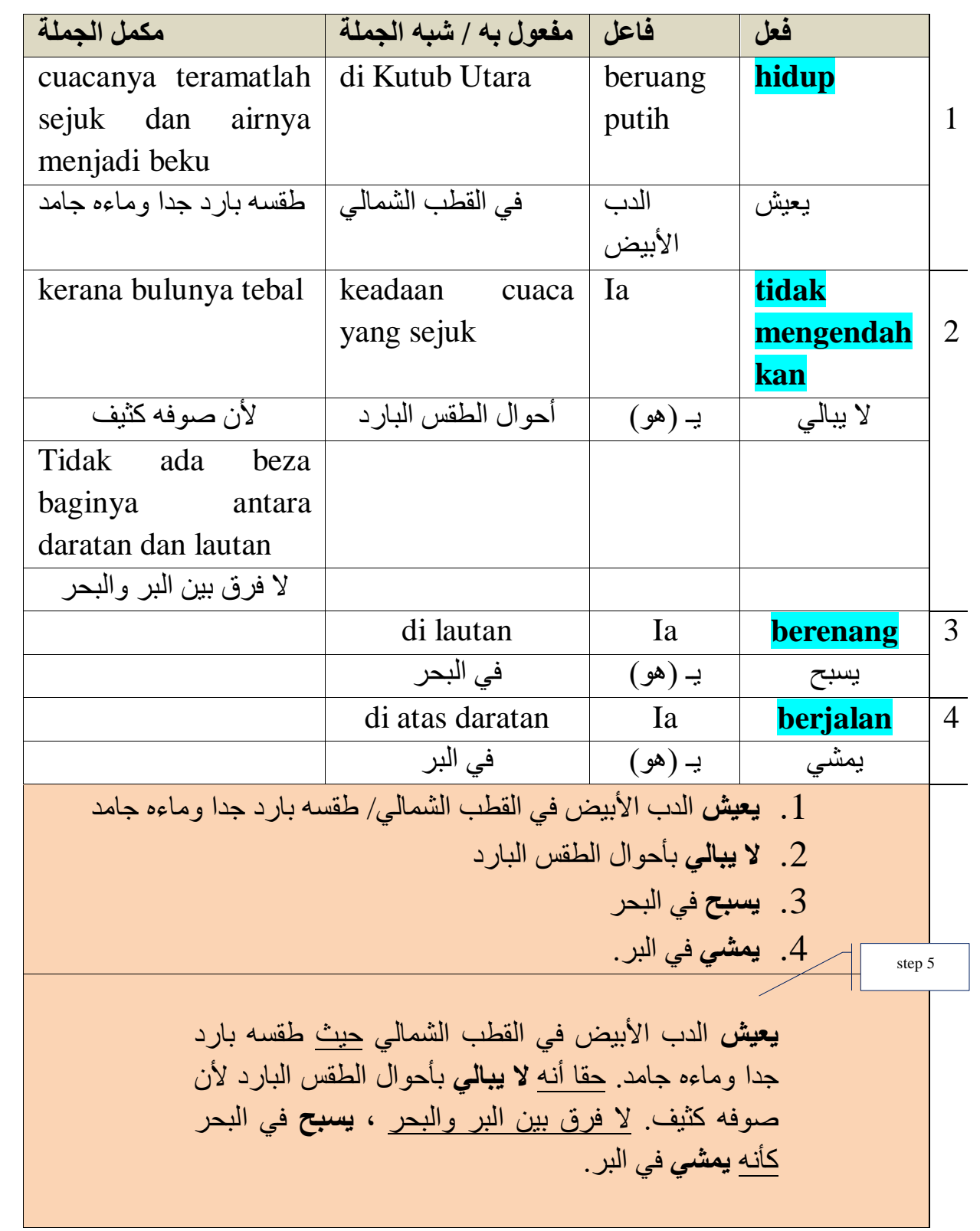

In the fifth step, students use their own skills to connect from one sentence to another to form a perfect paragraph. These skills are usually acquired by students who are proficient in Arabic. If the student has successfully completed the fourth step of the technical translation, training objective has been achieved. Lecturers only need to complete $\mathrm{T} \& \mathrm{~L}$ by teaching the skills of completing sentences in step five (Al Muhsin \& Ahmad, 2020). Capability of forming varied sentences in step five is an added value for students in learning sentence structure translation as the following:

Option 1

يعيش الدب الأبيض في القطب الثمالي حيث طقسه بارد جدا

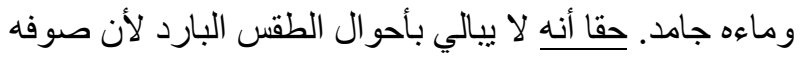

لا فرق بين البر والبحر ، يسبح في البحر كأنها يمشي في كثيف.

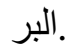

Option 2

$$
\begin{aligned}
& \text { يعيش الدب الأبيض في القطب الثمالي. روكان }
\end{aligned}
$$

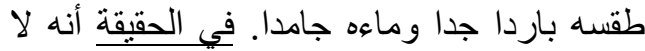

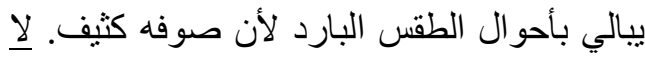

$$
\begin{aligned}
& \text { يفرق بين البر والبحر ، يسبح في البحر كما ليال }
\end{aligned}
$$

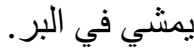

Students are also given the freedom to add words and change style of language as long as they do not swerve away from delivering meaning such as changing the verb phrase to noun phrase. In this step, students are practising the natural translation theory by Nida and Taber (2003) that prioritizes 
message delivery despite changes to the original text.

$$
\text { في القطب الأبيض يعيش ـ بعيش الدب الأبيض في القطب الثمالي }
$$

Or changing the structure such as taqdim or ta'khir which is to change the structure of several sentences from front to back or vice versa such as: لا فرق بين البر والبحر ، يسبح في البحر كما يمشي في

$$
\text { البربح في البحر كما يمشي في البر، لا فرق بين }
$$

\section{Example: Exercise 2}

Text 2 was randomly selected from Bernama to train students' ability to master media terms and styles.

MKN adakan mesyuarat tergempar petang ini - 7 MAC 2017

"KUALA LUMPUR - Majlis Keselamatan Negara (MKN) akan mengadakan mesyuarat tergempar petang ini berhubung tindakan Korea Utara menyekat rakyat Malaysia daripada meninggalkan negara itu. Sumber memberitahu Bernama mesyuarat tertutup itu akan dipengerusikan Perdana Menteri, Datuk Seri Najib Tun Razak di
Pangkalan Udara TUDM Subang pukul 6 petang ini, sebaik pulang daripada menghadiri Sidang Kemuncak Pemimpin Persatuan Negara-Negara Pesisir Lautan Hindi (IORA) di Jakarta. Mesyuarat dijangka dihadiri Timbalan Perdana Menteri Datuk Seri Dr Ahmad Zahid Hamidi, pegawai kanan Polis Diraja Malaysia, Jabatan Imigresen, MKN dan agensi-agensi yang terlibat dengan penguatkuasaan undang-undang dan keselamatan negara."

KUALA LUMPUR - Majlis Keselamatan Negara (MKN) akan mengadakan mesyuarat tergempar petang ini /berhubung tindakan Korea Utara / menyekat rakyat Malaysia daripada meninggalkan negara itu.

1. Majlis Keselamatan Negara (MKN) akan mengadakan mesyuarat tergempar petang ini / berhubung tindakan Korea Utara

2. menyekat rakyat Malaysia

\begin{tabular}{|c|c|c|c|c|}
\hline مكمل الجملة2 Jadual & مفعول به / شبه الجملة & فاعل & فعل & step 4 \\
\hline $\begin{array}{l}\text { berhubung tindakan } \\
\text { Korea Utara }\end{array}$ & $\begin{array}{c}\text { mesyuarat } \\
\text { tergempar petang } \\
\text { ini }\end{array}$ & $\begin{array}{c}\text { Majlis } \\
\text { Keselamat } \\
\text { an Negara } \\
(\mathrm{MKN})\end{array}$ & $\begin{array}{l}\text { akan } \\
\text { mengad } \\
\text { akan }\end{array}$ & \\
\hline حول قرار كوريا الثمالية & اجتماعا طارئا & 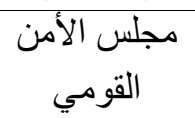 & سيعقد & \\
\hline & $\begin{array}{l}\text { rakyat Malaysia } \\
\text { daripada } \\
\text { meninggalkan } \\
\text { negara itu }\end{array}$ & $\begin{array}{l}\text { Korea } \\
\text { Utara }\end{array}$ & $\begin{array}{c}\text { menyek } \\
\text { at }\end{array}$ & \\
\hline & المالزيين من مغادرة & 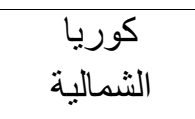 & تمنع & \\
\hline \multicolumn{4}{|c|}{ تمنع كوريا الثمالية لمالزيين من مغادرة البلادئاد القول قرار كوريا الثمالية } & \\
\hline \multicolumn{4}{|c|}{ 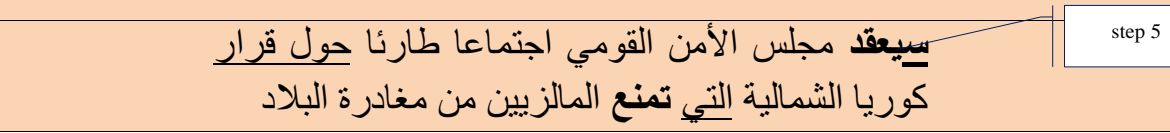 } & \\
\hline
\end{tabular}
daripada meninggalkan negara itu. 
In this exercise, students are given the opportunity to add and remove unnecessary words in Sوريا الثمالية Sentences such as the repeated noun which appeared twice.

The five steps procedure focuses solely on developing verb sentences to train students to get used to the standard Arabic language writing (Al Muhsin et al., 2020). Students are given regular training so that their skills improved and practised consistently within $\mathrm{T} \& \mathrm{~L}$ when they are at university or at school.

\section{Conclusion}

The outcome of the implementation of this procedure in $\mathrm{T} \& \mathrm{~L}$ of translation course among UPSI students of Bachelor of Arabic Studies with Education solve some of the difficulties faced by students in translating Malay-Arabic texts which is considered difficult by most students. This method helps students to formulate Arabic sentences in structure and at the same time the translator can understand the text to be translated through sentence categorization practices. This procedure is suitable for students who are already proficient in Arabic syntax and morphology, while poor students will have difficulty and take longer to complete the fourth and fifth steps of the procedure. At the same time, students will be able to learn writing techniques and also understand the text based on their study of the effect of verb sentence phrases. This procedure is expected to produce as translation tools in developing a method of translation in teaching and learning of Malay-Arabic translation courses.

\section{REFERENCE}

[1] Ali, A. S. (2013). The verbal system of Malay and Arabic: Contrastive analysis. International Journal of Business and Social Science, 4(1).

[2] Al Muhsin, M. A., Mohd, K. N., Muhammad, A. S., Osman, Z., Makki, S., \& Etigani, M. A. M. A. (2020). THE CHARACTERISTICS OF PROPOSE
ARABIC LANGUAGE MODULE FOR THE PURPOSE OF TOURISM: A CASE STUDY ON TOURISTS'MOSQUE IN KUALA LUMPUR. Journal of Critical Reviews, 7(14),

http://dx.doi.org/10.31838/jcr.07.14.89

[3] Al Muhsin, M. A., \& Ahmad, N. Z. (2020). The Emergence of Education 4.0 Trends in Teaching Arabic Islamic Finance Curriculum Design: A Case Study. International Journal of Psychosocial Rehabilitation. Vol. 23(4), p. 1019 - 1031.

[4] Al Muhsin, M. A., Ahmad, N. Z., Sarudin, A., Muhammad, M. M., Othman, Z., Makki, S., \& Kassymova, G. K. (2020). The Implementation of SCL in Teaching Arabic for Islamic Finance: A Dynamic Approach in Preparing for Education 4.0. International Journal of Psychosocial Rehabilitation. Vol. 24(9), p. 279 - 290.

[5] Mezah, C. R. (2009). Kesilapan leksikal dalam pembelajaran bahasa Arab. Penerbit Universiti Putra Malaysia.

[6] Abd Rahman, G. Y., \& Salleh, A. (2006). Kemahiran menulis tulisan arab dl kalangan pelajar-pelajar UiTM: kelemahan dan cara mengatasinya.

[7] Jassem, J. A. (2000). Study on second language learners of Arabic: An error analysis approach. Kuala Lumpur, Malaysia: AS Noordeen.

[8] Nida, Eugene A and Charles R. Taber (2003). The Theory and Practice of Translation. Leiden: E.J. Brill.

[9] Noor Anida binti Awang, Norhayati binti Che Hat, Nurazan binti Mohmad Rouyan. (2014). Analisa Kelemahan Kemahiran Menulis Bahasa Arab Dalam Kalangan Pelajar Unisza. Prosiding Seminar Pengajaran \& Pembelajaran Bahasa Arab 2014. Fakulti Pengajian Islam, UKM \& Fakulti Kontemporari Islam, UniSZA. 
[10] Samah, R. (2012). Pembinaan Ayat Bahasa Arab Dalam Kalangan Lepasan Sekolah Menengah Agama. GEMA Online ${ }^{\circledR}$ Journal of Language Studies, 12(2).

[11] Sumaiyah Sulaiman, Nik Farhan Mustapha, Pabiyah Toklubok@Hajimaming, Wan Muhammad Wan Sulong. (2018). Permasalahan Kemahiran Menulis Bahasa Arab dalam Kalangan Pelajar Peringkat Pengajian Tinggi. JURNAL SULTAN ALAUDDIN SULAIMAN SHAH VOL 5 BIL 2 (2018).

[12] Saipolbarin, R., Zarima, M. Z., Nazri, A., \& Mohammad Sidik, A. (2018). Aplikasi Formula Pola Ayat Dalam Penulisan Teks Pelajar Universiti Pendidikan Sultan Idris (UPSI). Jurnal Sultan Alauddin Sulaiman Shah, 5(1), 175-184.

[13] Saipolbarin Ramli, Mohammad Taufiq Abdul Ghani, Mohd Zawawi Awang Hamat. (2019). Media Interaktif Formula Pola Ayat Kata Kerjaan Bahasa Arab Untuk Bukan Penutur. International Journal of Humanities, Philosophy, Language. Volume: 2, Issues: 5, pp.13-24.

[14] Romli, T. R. M., \& Jumingan, M. F. (2015). Open Source Corpus as a Tool for Translation Training. European Journal of Language and Literature, 1(3), 60-68. https://dx.doi.org/10.26417/ejls.v3i1.p6068

[15] Zulkifli Junoh. (2000). Jumlat Ismiyyat dan Jumlat $i$ liyyaț: Satu Kajian Kes Terhadap Bahasa Arab Pelajar Tingkatan Empat dan Lima Sek. Men. Keb. Agama Kelantan: Tesis yang tidak diterbitkan, Universiti Malaya: Kuala Lumpur. 